\title{
The Disparity in Inflation Rates between the Group of Twenty (G20) and the Sub-Saharan Africa (SSA)
}

\author{
Mbetid Bessane Oïdy Purifice \\ Management Department, Nanjing University of Information Science and Technology, Nanjing, China \\ Email: oidymbetid@outlook.fr
}

How to cite this paper: Purifice, M. B. O. (2021). The Disparity in Inflation Rates between the Group of Twenty (G20) and the Sub-Saharan Africa (SSA). Technology and Investment, 12, 196-216. https://doi.org/10.4236/ti.2021.124012

Received: July 13, 2021

Accepted: November 9, 2021

Published: November 12, 2021

Copyright (อ 2021 by author(s) and Scientific Research Publishing Inc. This work is licensed under the Creative Commons Attribution International License (CC BY 4.0).

http://creativecommons.org/licenses/by/4.0/

\begin{abstract}
Given the changing challenges and obligations of current economic growth, inflation appears to have become an arbiter between the level of economic growth and the level of the general economy. Indeed, despite its economic pressure nature, inflation is sometimes used as an instrument of monetary equilibrium. However, if we look at previous studies, we see a clear disparity in inflation rates between developed and developing countries. The purpose of this paper is to understand this disparity, to analyse it and to give it consideration.
\end{abstract}

\section{Keywords}

Disparity, Inflation Rate, Group of Twenty, Sub-Saharan Africa

\section{Highlights}

- The inflation rates of the Group of Twenty (G20) and Sub-Saharan Africa (SSA) will be analysed: their origins, their resolution strategies, and their consequences. The comparison between the inflation rate of those regions will be made and the analyses on their disparity.

- The relationship between the level of development and the rate of inflation will be analysed. The level of development will be represented by the import-export rate, the unemployment rate, the outflow rate of foreign direct investment and the gross savings rate.

- The G20 is made up: G8 countries (United States, Japan, Germany, United Kingdom, France, Italy, Canada, and Russia), eleven industrialized or emerging countries: Argentina, Australia, Brazil, China, India, Indonesia, Mexico, Saudi Arabia, South Africa, South Korea, Turkey, and the European Union,

- Sub-Saharan Africa is made up of: Angola, Benin, Botswana, Burkina Faso, 
Burundi, Cameroon, Cape Verde, Central African Republic, Chad, Comoros, Côte d'Ivoire, the Democratic Republic of the Congo, Equatorial Guinea, Eritrea, Ethiopia, Gabon, Gambia, Ghana, Guinea, Guinea-Bissau, Kenya, Lesotho, Liberia, Madagascar, Malawi, Mali, Mauritania, Mauritius, Mozambique, Namibia, Niger, Nigeria, Republic of the Congo, Rwanda, Sao Tome and Principe, Senegal, Seychelles, Sierra Leone, Somalia, South Africa, South Sudan, Sudan, Swaziland, Tanzania, Togo, Uganda, Zambia, Zimbabwe.

\section{Introduction}

In the 1990s, Sub-Saharan Africa posted growth rates of around 5\% - 6\% per annum. The general level of the economy improved with decreasing poverty rates and improvements in several social indicators. The exploitation and rise in world prices, followed by the acceleration of growth in many component countries, have allowed the region's economic situation to show interesting macroeconomic results. Part of these results is also due to the emergence of oil producers such as Equatorial Guinea and Chad, which recorded growth rates of $38 \%$ and $28 \%$ respectively in 2004. With increased oil production in Angola, Nigeria and many others, followed by the emergence of investment, have also made a real contribution. Non-resource exporting countries such as Ethiopia, Uganda, Mozambique, Rwanda, etc. have expanded strongly. The implementation of some economic policies has led to a decline in inflation and a corresponding improvement in business investment. Not to mention the ease of credit provision by financial institutions. However, the region's economy is still challenged by several vagaries such as reliance on food imports, the steady recovery of the general economy due to socio-political unrest, and a significant slowdown, which resulted in a real blow to oil and mineral exporting countries followed by a weakening of commodity prices.

The Group of Twenty (G20) is the gathering of the world's 20 major industrialized and emerging economies. The data revealed in the second quarter of 2020, growth in the real gross domestic product (GDP) of all G20 states. However, in the fourth quarter, Indonesia saw its GDP fall by $2.9 \%$ compared to the previous quarter. In 2019, that of the United States has advanced to 21.43 trillion US dollars and that of China estimated at 14.4 trillion US dollars. The statistics project GDP growth of US\$8.6 trillion for China in 2025 and US\$4 trillion for the US GDP. The statistics show high inflation rates for the entire Sub-Saharan Africa (SSA) region over the past five years of 3.8\%, 5.3\%, 5.18\%, 3.91\%, 2.73\%, $3.22 \%$ respectively, outpacing the overall annual growth rate over the same period. In the same period, the G20 region shows a moderate inflationary evolution of $3.07 \%, 2.74 \%, 2.79 \%, 3.25 \%, 2.69 \%, 2.39 \%$ respectively with a rather controlled geometric trend. Its growth rates, on the other hand, seem to follow a good arithmetical trend. The result of the comparison of the statistical data of the two regions together reveals a disparity. There has been a lot of previous work on the causal relationship between the inflation rate and economic growth. The scope of the analysis of this relationship has been limited to the non-linearity between these two variables, but it has not touched on the causality between the 
level of development of a country and its level of inflation.

The present paper is of particular interest in this new scope. Indeed, six variables will be highlighted: the inflation rate, the level of development of the countries marked by the two regions (G20 and SSA) which will be represented by the import-export rate, the unemployment rate, the outflow rate of foreign direct investment and the gross savings rate. Thus, the causal link between the level of development of these regions and their inflation rate will be analysed by highlighting the correlation between the inflation rate and these different rates. The data will be considered separately for each region.

The paper is structured as follows. The second section will provide an overview of the literature on inflation, the third section will summarise the data collected for the G20 and Sub-Saharan Africa. The fourth section will discuss the econometric model used; the fifth section the empirical results. And the last section concludes.

\section{Literature Review}

In today's economic world, it is impossible to talk about the economy without mentioning inflation. It is defined by its resurgence in the face of some stimulating economic situations due to accelerated growth linked to the increase in global demand, the rise in the costs of some products such as raw materials, the increase in the wage bill which implies an increase in the income available for consumption and at the same time in company costs. The anticipation of inflation which often pushes economic agents to take some positions such as price increases is also an inflationary factor. But the most obvious one is the set of monetary policies put in place by each country to regulate it, or even tame it. Indeed, several previous empirical studies affirm the existence of a non-linear relationship between inflation and growth. The foundations were laid by Fisher (1993) with the notion of non-linearity. For him, the impact of inflation on growth varies according to its rate. When the rate increases, the impact becomes negative and vice versa. At the same time, Sarel (1996) reported an inflation rate of $8 \%$, which he considers as an equilibrium threshold, beyond which inflation would harm economic growth. However, it will have an insignificant effect. Khan and Senhadji (2001) reach the same results on a threshold of $11 \%$ for developing countries. Ghosh and Phillips (1998) also conclude in their work that the level of inflation determines its relationship with growth. A low rate implies a positive relationship and vice versa.

In the same vein, Bruno and Easterly (1998) assert a possible relationship between high inflation and growth but remain doubtful about their causality. According to them, an inflation crisis is often synonymous with declining growth, but its reduction is followed by a recovery in growth. In their work, Gillman and Kejak (2005) experimented with this non-linearity through a model linked to goods. The increase in the inflation rate leads to an increase in the exchange rate of goods. This leads to a substitution from consumption to leisure. This has a negative impact on economic growth. All this work has given new scope to the 
economy. Because many states have put in place monetary strategies to adopt inflation, Cheikh and Mamadou (2017) also support the dependence of macroeconomic policies on the level of inflation. However, they point out that the upward trend in inflation leading to an increase in the interest rate could be bad for growth, as it will lead to increased borrowing and reduced investment. This is confirmed by Gali and Monacelli (2008), who argue that it would be optimal for a country to have its monetary authority and its fiscal and budgetary authorities work in coordination to stabilize inflation. They advocate a dual function for the fiscal authority, including trade-offs in the provision of public goods but also stabilization of inflation. Cheikh and Mamadou (2017) highlight four reasons that may cause inflation in Sub-Saharan African countries, including the fiscal deficit, currency issuance, external shocks, and the type of exchange rate regime. This is supported by Loungani and Swagel (2001), who consider exchange rates in African developing countries as one of the reasons for the variation in their inflation; according to their results, these would account for 14 to 18 percent of the variation in inflation. In the same vein, the results of studies by Barnichon and Peiris (2008) also point out that the causes of inflation in Sub-Saharan African countries are the output gap, money (regarding the gap between money supply and demand) and rainfall. Taylor (1993) refers to high output variance as the cost of price stability. The result of the study of some authors such as Bick, Kremer and Nautz (2009) shows a prime rate of inflation at 2\%. For other authors such as Evans (1991), Holland (1995), Grier and Perry (1998), Daal, Naka and Sanchez (2005), Fountas, Karanasos and Kim (2007), it is inflation uncertainty that causes inflation to rise. Indeed, for these authors, inflation uncertainty will lead economic agents (firms, households, etc.) to implement protection strategies, which will ultimately lead to an increase in inflation. Obviously, this approach is rooted in many inflationary facts, in particular the increase in the money supply that follows the increase in market prices and the increase in business costs. Dotsey and Sarte's (2000) basis of analysis is more related to duration. For them, in the short run, inflation and growth are positively correlated, resulting in an inverse effect in the long run. They point out that, because of the variability of inflation, uncertainty about future income will lead to an increase in savings in the short run that will result in growth in the medium run.

Other authors have addressed inflation in terms of these determinants. Rudra, Mak and Sahar (2015) for instance, have highlighted the relationship between economic growth, inflation, and stock market developments simultaneously. Their result reveals a unidirectional causality from economic growth, stock market development to inflation in the short and long run. However, based on the Granger model, their analysis assumes an influence of economic growth and stock market development on inflation in the short run. Thus, they remain equivocal on this long-run relationship. Siok, Xue and Yen (2015) focus on the effects of oil price changes on inflation by highlighting low and high oil dependency groups. Their result confirms a long-term relationship between oil price changes and CPI (Consumer Price Index) by highlighting that these changes 
have significant effects on the determination of domestic inflation, varying directly and indirectly between the low and high oil dependency group. Michael and William (1998) on the other hand assert a strong and robust relationship between high inflation and growth, however, causality is uncertain. This is because according to them, real supply-side causes could not be found to justify the negative growth-inflation relationship. However, they point out that a high inflation crisis is linked to low growth and the end of this crisis is linked to high growth. Abdul, Rabbia and Nazia (2014), on the other hand, focus on the fiscal deficit as one of the drivers of inflation. Their result shows that the budget deficit has a positive impact on inflation in the long run. They solve the alternative of fiscal consolidation with the need to set some threshold for the fiscal authorities and make monetary policy less dependent. Sargent and Wallace (1981), Luis and Marco (2005) shared the same idea in their results. Nezir, Furkan and Sergin (2012) find a long-term cointegration between the short-term interest rate and the expected inflation rate. They base their analysis on the decline in real interest rates which will lead to an increase in real output and a corresponding increase in the inflation rate. Igor (2006), on the other hand, approaches the relationship between inflation and monetary demand. He points out that monetary variables, except the refinancing rate, influence inflation in the short run and the monetary gap has a significant impact on inflation in the long run. Peter and Hakan (2009) in their study analyses the relationship between finance, inflation, and growth. Their result shows that high inflation disrupts the finance-growth relationship. However, this disruption is less evident in periods of low inflation but is strongly negative to the upward variation in inflation.

All these authors have highlighted some determinants of inflation but have not considered the level of development of a country. They have relied heavily on economic and monetary concepts such as the level of growth, stock market developments, oil prices, budget deficit, interest rate, finance, monetary variables, etc. It is obvious that these facts are really determinants of inflation, but they do not consider the development aspect, which considers several aspects, including the level of unemployment, import-export, direct foreign investment, and gross savings, which are also aspects highlighted in previous literature as justifying the growth and development of a country, thus, to explain the disparity between the inflation rate between developed and developing countries. Indeed, one of the concerns that previous studies have not addressed is the issue of the disparity in inflation rates between developed and developing countries. This disparity is quite intriguing when one notes that the inflation rate in developed countries is often low or regulated. But it varies upwards in developing countries.

\section{Collecting Data}

An overview of statistical and empirical evidence over the past 23 years provides an understanding of the causality between the level of development of these two regions (G20 and Sub-Saharan Africa) and their inflation rates. It also defines the cointegration between the inflation rate, the unemployment rate, the import-export 
rate, the rate of outward foreign direct investment and the gross savings rate.

\subsection{Background}

Table 1 is a summary of the set of variables used in the empirical model. Figure 1 and Figure 2 show the trend of these different variables in the G20 region and the Sub-Saharan Africa region. Figure 3 and Figure 4 present together with the

Table 1. Composition of the empirical model.

\begin{tabular}{|c|c|}
\hline Variables & Explanation \\
\hline INFLR & $\begin{array}{l}\text { Inflation Rate: Inflation is a sustained and widespread increase in prices } \\
\text { resulting in a loss of purchasing power of money. }\end{array}$ \\
\hline IMPR & Importation Rate: Requesting or purchasing from international suppliers. \\
\hline EXPR & Exportation Rate: Bidding or selling to international customers. \\
\hline UER & $\begin{array}{l}\text { Unemployment Rate: is the situation of a person who is out of work and } \\
\text { looking for a job. }\end{array}$ \\
\hline FDIR & Foreign direct investment Rate: is an international capital flow or transfer. \\
\hline GSAVR & $\begin{array}{l}\text { Gross Saving Rate: is a resource available to finance investments or repay } \\
\text { debts. }\end{array}$ \\
\hline
\end{tabular}

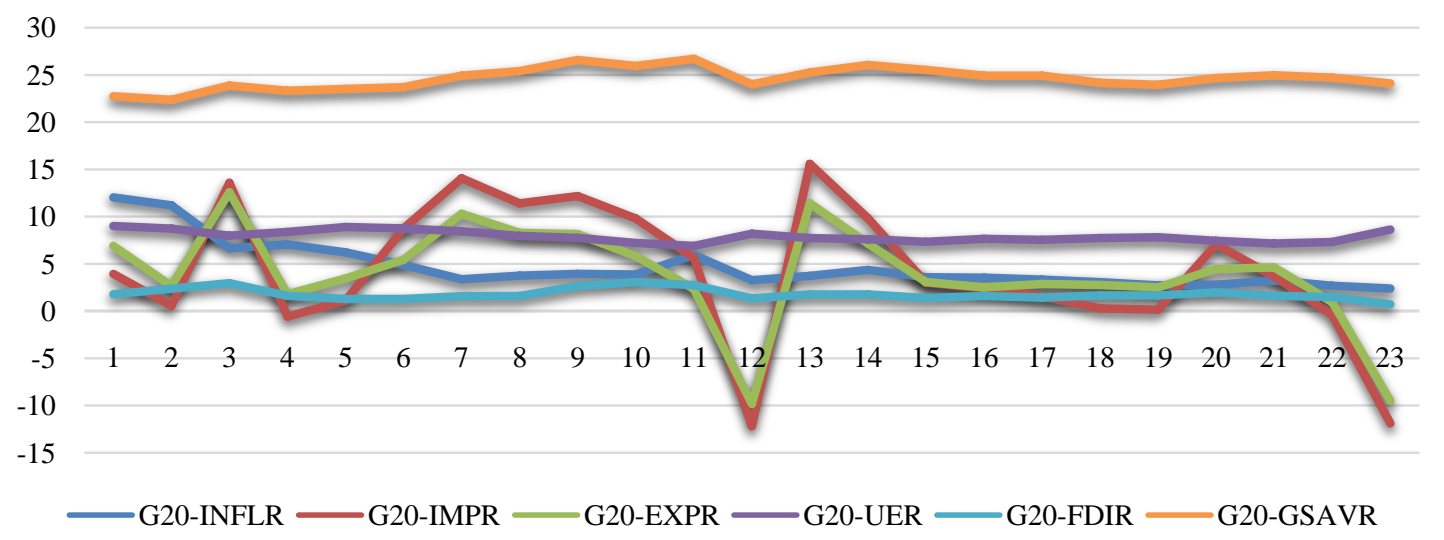

Figure 1. G20 Database. Source: Based on World Bank data (World Bank) (The 23 years are represented horizontally and the rates of the various variables are represented vertically).

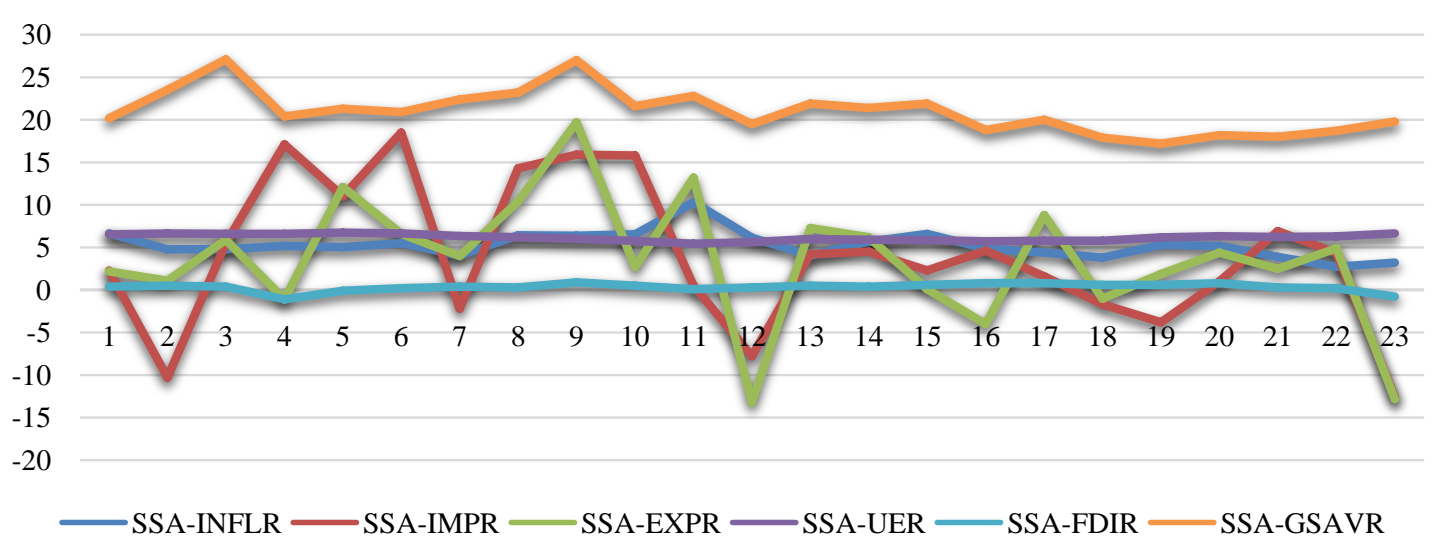

Figure 2. SSA Database. Source: Based on World Bank data (World Bank) (The 23 years are represented horizontally and the rates of the various variables are represented vertically). 
trend of the gross domestic product and the inflation rate of the two regions successively. Looking at past inflation and GDP statistics, particularly in Figure 1 and Figure 2, we see a gap between the inflation rates of the G20 region and those of Sub-Saharan Africa. A gap would hint at an arithmetic trend when considering the evolution of the inflation rate of Sub-Saharan Africa as a whole. On the other hand, if we look at the overall trend in inflation and GDP in the context of the two regions combined, there is some disparity between the two sets. Indeed, there is an upward trend in inflation in the Sub-Saharan countries, which is putting some pressure on growth. In contrast, the opposite is true in the G20 countries, where the trend shows moderation.

In general, inflation is not directly linked to an economic anomaly, as it presupposes the presence of growth. However, inflation becomes harmful when it is not moderate and its rate spills over. This will lead successively to stagflation, hyperinflation and recession. The fourth quarter of 2019 and the year 2020 were disrupted by the COVID-19 epidemic, which is reflected in the growth and inflation rates of these periods. However, the inflation rate of the G20 countries seems to remain in its normal rhythm, even if the growth rate has taken a hit. This contrasts with Sub-Saharan Africa, where the inflation rate has increased despite the decline in the growth rate.

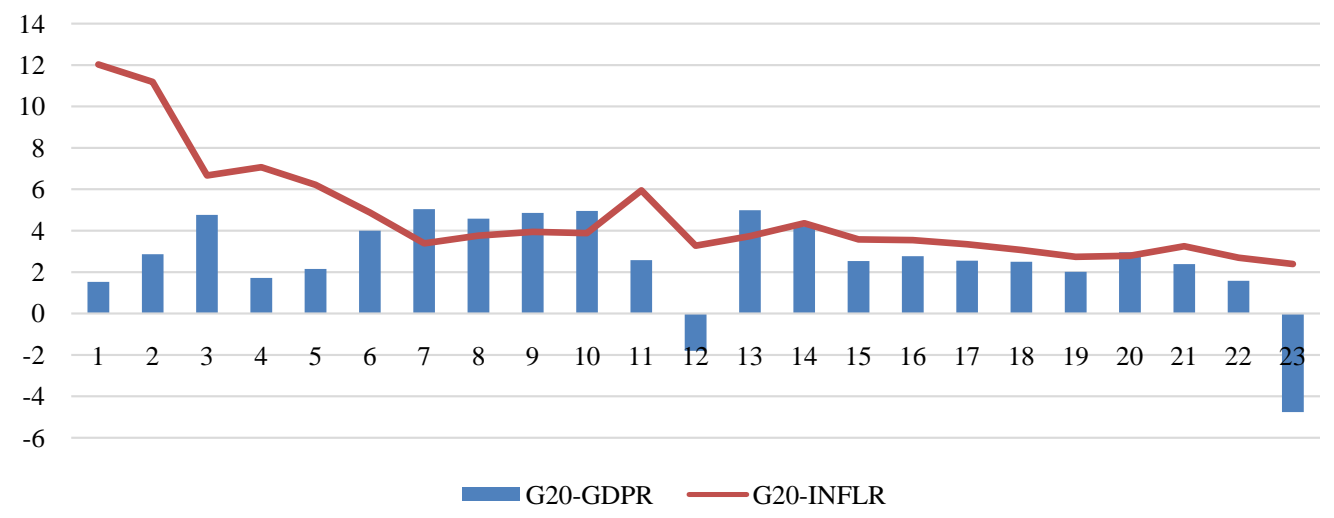

Figure 3. G20 GDPR and INFLR. Source: Based on World Bank data (World Bank) (The 23 years are represented horizontally and the rates of the various variables are represented vertically).

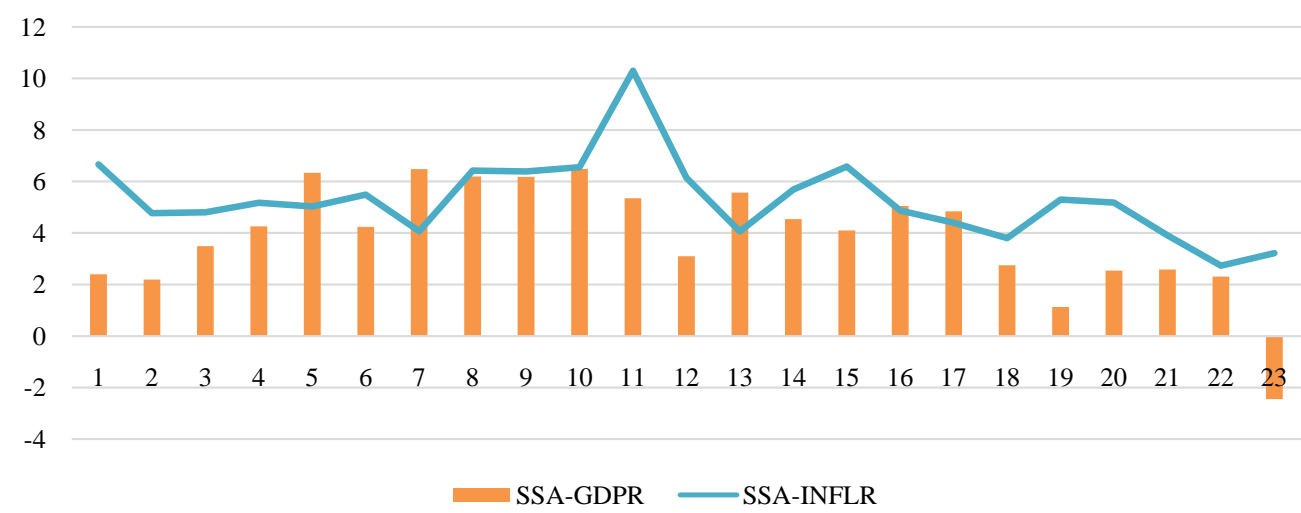

Figure 4. SSA GDPR and INFLR. Source: Based on World Bank data (World Bank) (The 23 years are represented horizontally and the rates of the various variables are represented vertically). 
It should also be noted that the exchange rate regime is different in the two regions. Most SSA countries have flexible exchange rates, with the exception of the CFA franc zone countries that form a monetary union. Thus, SSA countries with flexible exchange rate regimes may decide to change if there is a significant upward trend in inflation. As Masson (2000) points out in his study, exchange rate regimes are not fixed in time and can switch according to the evolution of the authorities' objectives. This transition between regimes is comparable to a stochastic process. Such as the case of Nigeria in late 2014, while in the G20 countries, most adopt fixed exchange rates, which allow their Central Banks to manage inflationary pressures downwards or upwards depending on the projected objective, which is mainly the search for macroeconomic balance in order to boost the general economy and regulate economic growth. These differences between the exchange rate regimes bring us back to the results of Levy-Yeyati \& Sturzenegger (2007) who pointed out that the fixed exchange rate regime is associated with low nominal exchange rate volatility and high foreign exchange reserve volatility. While the flexible exchange rate regime is associated with high nominal exchange rate volatility but low foreign exchange reserve volatility.

\subsection{Retrospective}

According to the February 2015 IMF (IMF, 2015), in general, the economy of the G20 countries has a relevant pace. In the interval of 2015 to 2016, there has been a drop in oil prices, manifested by an increase in production in the United States. This was followed by the decision of the Organization of the Petroleum Exporting Countries (OPEC) to maintain this production trend, in order to stimulate global growth. This has influenced consumption in the US. However, this has led to a hindrance to investment, which has nega-tively influenced growth in the short term. From the G20 States Summit report written by Diez and O'Donnell (2017). In Japan, there was a recession in the last quarters of 2014 due to the consumption tax increase. In the Eurozone, weak investment led to lower growth towards the end of 2014. In China, towards the end of 2014, the growth rate was $7.4 \%$. Furthermore, in 2016 there was a budget deficit in most G20 countries, as well as high levels of gross debt in some, notably Japan and the UK.

According to the World Bank statistic for June 2015, GDP growth in Sub-Saharan Africa decreased from 5.05\% in 2013 to $4.84 \%$ in 2014. Between the end of the second quarter of 2014 and the beginning of 2015, in contrast to other commodity prices, oil prices fell by about $50 \%$, and have maintained their trend. Global Economic Prospects of 2015 Sub-Saharan Africa analysis (Global Economic Prospects, 2015) revealed that at Nigeria, the downward revision of oil prices on expected revenues was followed by a reduction in government spending. To address this, the central bank reverted to a fixed exchange rate regime in the inter-bank market. However, this devaluation will add to price pressures in Nigeria. Towards the end of 2015, the Angolan central bank adjusted its exchange rate following the devaluation of its currency. Several countries in the Sub-Saharan region (Cameroon, Chad, Congo Brazzaville, Central African Re- 
public, Equatorial Guinea and Gabon) use the CFA franc, which is pegged to the euro. So, when the euro depreciated against the dollar, the CFA franc also depreciated against the dollar. In addition, the fall in fuel prices contributed to lower inflation in early 2015.

Declining commodity prices, difficulties with financial conditions and a delayed policy response have been at the root of SSA's economic slowdown, despite its multi-speed growth. This is because non-commodity exporting countries in the region are growing at around $4 \%$. However, this slowdown is affecting commodity-exporting countries to a large extent and is leading to economic tensions. This is the case for Nigeria, Angola, the Democratic Republic of Congo, Ghana, Zambia, Zimbabwe and many others in Central Africa. The 2016 IMF report written by Newiak (2016) motivates countries outside a monetary union to adopt a flexible exchange rate to better counter inflation and reduce budget deficits for a longer period. For countries in a monetary union (notably the CFA Franc zone) relying on a fixed exchange rate regime, the Central Bank should reduce the financing of excessive budget deficits.

Towards the end of 2018, in Sub-Saharan Africa, there was a slowdown in the recovery from the unrest in 2015. Declining oil production in Angola and Nigeria lowered oil prices. The opposite was true for their Central African peers who benefited from higher oil prices and increased oil production. In South Africa, agricultural activity declined as a result of weak household consumption. On the other hand, economic activity supported by agricultural production and services, household consumption and public investment remained stable in Côte d'Ivoire, Kenya and Rwanda. In addition, interest rate caps are one of the most widely used policies. 17 countries in Sub-Saharan Africa use interest rate caps. Some countries use a single cap and others use multiple caps varying under some conditions. This is the case of South Africa with multiple caps and Kenya with a single cap.

The interest rate is a permanent instrument of monetary policy. In developing countries, high interest rate initiatives are usually linked to compensating for the risk of future depreciation. While in developed countries, an interest rate is often linked to growth regulation. The results of Camara's (2014) study on Sub-Saharan African countries show that countries in the CFA zone generally have low interest rates, which is the opposite for countries outside the CFA zone. For countries outside the CFA zone, the interest rate is lower for those with a fixed exchange rate regime and higher for those with a flexible exchange rate regime. For him, the inflation rate is lower for CFA zone countries than for not CFA zone countries whose inflation is high. It should also be noted that interest rates in Sub-Saharan African countries vary in parallel with inflation rates. The Central Bank of the zone acts on the relationship between inflation and interest rate. When inflation rises, the Central Bank raises the interest rate and lowers it when it is needed to promote employment and growth.

\section{Methodology}

To better understand the problem, the sample was based on a random set of two 
groups, namely the Group of Twenty (G20) representing developed countries and Sub-Saharan Africa (SSA) representing developing countries. This choice was made by considering the defined criteria: level of development (high/low) and inflation rate (low/high). Then, the number of observations was constituted over the period from 1998 to 2020. Data were collected from various empirical and statistical sources on inflation in Africa and developed countries, including previous work, research platforms, World Bank database, and African economic reports or journals (macrotrends) (The World Bank).

Furthermore, due to the difficulties in obtaining generalized and concrete statistics of the elements of each sample set, it was important to conduct mathematical filtering of the data taken in detail in order to obtain a more suitable basis for our empirical analysis. In addition, the initial research and collection of information were done around various statistical database sources. This led to discrepancies in some statistical data. Thus, it was necessary to find a balance point between the different data, compare their trends, and consider those whose similarity is greater than or equal to three.

The qualitative analysis conducted through these different observations allowed us to understand that the inflation trend in developed countries is often moderate. While in developing countries, it has a positively volatile trend. The quantitative analysis through the empirical method used subtly underlines the causality between the level of development and the inflation rate.

The empirical process will be carried out in four steps:

The first step will be to check the stochastic property of the variables. To refine the regression results, we will analyse the stationarity of the data by the Augmented Dickey-Fuller (ADF) unit root test using the Schwarz criterion (SC) at the 1st difference. The second step will be to perform the Johansen (1991, 1995) cointegration test to analyse the long-term causality of the variables. Then, we will proceed with the vector error correction model (VECM) for this short-term causality with Wald Test to analyse the result. Finally, we conclude with the Breusch-Godfrey serial correlation LM test and the CUSUM residual stability test. Recall that the model is based on the relationship between the inflation rate and the level of development. The objective is to explain the variability of the inflation rate of a country according to its level of development characterized in the study by the rate of import-export, the rate of unemployment, the rate of outflow of foreign direct investment and the rate of gross savings.

\section{Empirical Results}

We considered the analysis of the data separately in the case of G20 and in the case of SSA.

\subsection{Augmented Dickey-Fuller (ADF) Unit Root Test}

The result of the ADF test allows us to see the level of integration (stationarity) of the variables. 
In Table 2 and Table 3 of ADF test, the null hypothesis assumes the presence of a unit root. This means that to reject the null hypothesis, the $p$-value must be less than the alpha. Here, we see that in both our cases (G20 and SSA), the $p$-values (0.0004) are lower than the alpha (0.05). Similarly, we see that the test statistic of the two cases are -3.788030 for the G20 and -3.808546 for the SSA are lower than their critical values (5\%) respectively -3.012363 and -3.020686 . Thus, let us conclude that the data are stationary and reject the null hypothesis.

Table 2. G20 ADF.

Null Hypothesis: D(G20_INFLR) has a unit root

Exogenous: Constant

Lag Length: 0 (Automatic-based on SIC, maxlag =4)

\begin{tabular}{lrcc}
\hline & t-Statistic & Prob. $^{*}$ \\
\hline Augmented Dickey-Fuller test statistic & -5.275243 & 0.0004 \\
\hline Test critical values: & $1 \%$ level & -3.788030 & \\
$5 \%$ level & -3.012363 & \\
$10 \%$ level & -2.646119 & \\
\hline
\end{tabular}

Table 3. SSA ADF.

Null Hypothesis: D(SSA_INFLR) has a unit root

Exogenous: Constant

Lag Length: 1 (Automatic-based on SIC, maxlag = 4)

\begin{tabular}{lrrr}
\hline & t-Statistic & Prob. $^{*}$ \\
\hline Augmented Dickey-Fuller test statistic & -5.316809 & $\mathbf{0 . 0 0 0 4}$ \\
\hline Test critical values: & $1 \%$ level & -3.808546 & \\
$5 \%$ level & -3.020686 & \\
$10 \%$ level & -2.650413 & \\
\hline
\end{tabular}

\subsection{Johansen Cointegration Test}

The Johansen Cointegration Test allows us to look for a long-term relationship between the variables.

In Table 4, the $\lambda_{\text {trace }}$ section shows that $\mathrm{r}=3$ with a t-statistic of 75.49908 which exceeds the critical value 47.85613 at the $5 \%$ level. Therefore, we can reject the null hypothesis of no cointegration, there is a cointegrating relationship between the variables. In our case, we had three cointegrating equations and it results in a cointegrating rank equal to 3 . The $\lambda_{\max }$ presents a similar result with an $r=3$ for a t-statistic of 47.83632 exceeding the critical value 27.58434 at the $5 \%$ level. In summary, the trace and max tests suggest a long-term cointegrating relationship between the variables.

In Table 5 of the SSA case, the $\lambda_{\text {trace }}$ shows that $\mathrm{r}=2$ with a t-statistic of 75.30315 which exceeds the critical value 69.81889 at the $5 \%$ level. Thus, the null 
Table 4. G20 johansen cointegration.

\begin{tabular}{|c|c|c|c|c|}
\hline \multicolumn{5}{|c|}{ Unrestricted Cointegration Rank Test (Trace) } \\
\hline Hypothesized & & Trace & 0.05 & \\
\hline No. of CE(s) & Eigenvalue & Statistic & Critical Value & Prob. ${ }^{* *}$ \\
\hline None ${ }^{\star}$ & 0.987459 & 231.5771 & 95.75366 & 0.0000 \\
\hline At most $1^{*}$ & 0.952807 & 139.6227 & 69.81889 & 0.0000 \\
\hline At most $2 *$ & 0.897503 & 75.49908 & 47.85613 & 0.0000 \\
\hline At most 3 & 0.580856 & 27.66276 & 29.79707 & 0.0864 \\
\hline At most 4 & 0.319934 & 9.402416 & 15.49471 & 0.3295 \\
\hline At most 5 & 0.060275 & 1.305539 & 3.841465 & 0.2532 \\
\hline \multicolumn{5}{|c|}{ Unrestricted Cointegration Rank Test (Maximum Eigenvalue) } \\
\hline Hypothesized & & Max-Eigen & 0.05 & \\
\hline No. of CE(s) & Eigenvalue & Statistic & Critical Value & Prob. ${ }^{* *}$ \\
\hline None ${ }^{*}$ & 0.987459 & 91.95443 & 40.07757 & 0.0000 \\
\hline At most $1^{*}$ & 0.952807 & 64.12358 & 33.87687 & 0.0000 \\
\hline At most $2 *$ & 0.897503 & 47.83632 & 27.58434 & 0.0000 \\
\hline At most 3 & 0.580856 & 18.26035 & 21.13162 & 0.1204 \\
\hline At most 4 & 0.319934 & 8.096877 & 14.26460 & 0.3690 \\
\hline At most 5 & 0.060275 & 1.305539 & 3.841465 & 0.2532 \\
\hline
\end{tabular}

Table 5. SSA johansen cointegration test.

\begin{tabular}{|c|c|c|c|c|}
\hline \multicolumn{5}{|c|}{ Unrestricted Cointegration Rank Test (Trace) } \\
\hline Hypothesized & & Trace & 0.05 & \\
\hline No. of CE(s) & Eigenvalue & Statistic & Critical Value & Prob. ${ }^{* *}$ \\
\hline None ${ }^{\star}$ & 0.900723 & 123.8098 & 95.75366 & 0.0002 \\
\hline At most $1 *$ & 0.792965 & 75.30315 & 69.81889 & 0.0171 \\
\hline At most 2 & 0.692642 & 42.23088 & 47.85613 & 0.1524 \\
\hline At most 3 & 0.363689 & 17.45631 & 29.79707 & 0.6063 \\
\hline At most 4 & 0.291320 & 7.962874 & 15.49471 & 0.4694 \\
\hline At most 5 & 0.034233 & 0.731495 & 3.841465 & 0.3924 \\
\hline
\end{tabular}

Unrestricted Cointegration Rank Test (Maximum Eigenvalue)

\begin{tabular}{ccccc}
\hline $\begin{array}{c}\text { Hypothesized } \\
\text { No. of CE }(\mathrm{s})\end{array}$ & Eigenvalue & $\begin{array}{c}\text { Max-Eigen } \\
\text { Statistic }\end{array}$ & $\begin{array}{c}\mathbf{0 . 0 5} \\
\text { Critical Value }\end{array}$ & Prob. $^{* *}$ \\
\hline None $^{*}$ & 0.900723 & $\mathbf{4 8 . 5 0 6 6 9}$ & $\mathbf{4 0 . 0 7 7 5 7}$ & 0.0045 \\
At most 1 & 0.792965 & 33.07226 & 33.87687 & 0.0621 \\
At most 2 & 0.692642 & 24.77457 & 27.58434 & 0.1099 \\
At most 3 & 0.363689 & 9.493436 & 21.13162 & 0.7907 \\
At most 4 & 0.291320 & 7.231379 & 14.26460 & 0.4621 \\
At most 5 & 0.034233 & 0.731495 & 3.841465 & 0.3924 \\
\hline
\end{tabular}


hypothesis of no cointegration will also be rejected. There are two cointegration equations resulting in a cointegration rank of 4 . The $\lambda_{\max }$ presents a different result with an $\mathrm{r}=1$ for a t-statistic of 48.50669 exceeding the critical value of 40.07757 at the $5 \%$ level. In the case of the max test, there's a cointegration equation resulting in a cointegration rank of 5 . However, both sections suggest a long-term cointegrating relationship between the variables.

\subsection{Vector Error Correction Model (VECM)}

The VECM allows us to look for a short-term relationship between the variables. Recall that the process of specifying the error correction model will be done in two steps: the establishment of the model followed by the Wald Test to determine if there is a short-term relationship between the variables.

In Table 6, the first section of the VECM model results output displays the long-run cointegration equation for the variables. The $\mathrm{ECT}_{\mathrm{t}-1}=1.000 \mathrm{~g} 20-\mathrm{inflr}_{\mathrm{t}-1}$ $+1.633 \mathrm{~g} 20-\mathrm{impr}_{\mathrm{t}-1}-2.245 \mathrm{~g} 20-$ expr $_{\mathrm{t}-1}-4.751 \mathrm{~g} 20-\mathrm{uer}_{\mathrm{t}-1}-0.789 \mathrm{~g} 20-\mathrm{fdir}_{\mathrm{t}-1}-$ $4.564 \mathrm{~g} 20-$ gsavr $_{\mathrm{t}-1}+148.6754$.

Table 6. G20 VECM.

\begin{tabular}{|c|c|c|c|c|c|c|}
\hline Cointegrating Eq: & CointEq1 & & & & & \\
\hline G20_INFLR(-1) & 1.000000 & & & & & \\
\hline \multirow{3}{*}{ G20_IMPR(-1) } & 1.633429 & & & & & \\
\hline & $(0.10338)$ & & & & & \\
\hline & [15.8003] & & & & & \\
\hline \multirow[t]{3}{*}{ G20_EXPR $(-1)$} & -2.245158 & & & & & \\
\hline & $(0.12471)$ & & & & & \\
\hline & {$[-18.0034]$} & & & & & \\
\hline \multirow[t]{3}{*}{ G20_UER(-1) } & -4.751397 & & & & & \\
\hline & $(0.37209)$ & & & & & \\
\hline & {$[-12.7694]$} & & & & & \\
\hline \multirow[t]{3}{*}{ G20_FDIR(-1) } & -0.789211 & & & & & \\
\hline & $(0.17881)$ & & & & & \\
\hline & [-4.41371] & & & & & \\
\hline \multirow[t]{3}{*}{ G20_GSAVR(-1) } & -4.564901 & & & & & \\
\hline & $(0.29340)$ & & & & & \\
\hline & {$[-15.5588]$} & & & & & \\
\hline $\mathrm{C}$ & 148.6754 & & & & & \\
\hline Error Correction: & D(G20_INFLR) & D(G20_IMPR) & D(G20_EXPR) & D(G20_UER) & D(G20_FDIR) & D(G20_GSAVR) \\
\hline \multirow[t]{3}{*}{ CointEq1 } & -0.413823 & 0.548314 & 0.519291 & -0.007024 & -0.041499 & 0.026546 \\
\hline & $(0.10144)$ & $(0.75279)$ & $(0.55926)$ & $(0.05951)$ & $(0.06720)$ & $(0.09612)$ \\
\hline & {$[-4.07936]$} & [0.72837] & [0.92854] & {$[-0.11803]$} & {$[-0.61756]$} & {$[0.27618]$} \\
\hline
\end{tabular}




\begin{tabular}{|c|c|c|c|c|c|c|}
\hline \multicolumn{7}{|l|}{ Continued } \\
\hline \multirow[t]{3}{*}{ D(G20_INFLR(-1)) } & -0.303608 & -0.999052 & -0.601338 & 0.042117 & 0.038443 & -0.130220 \\
\hline & $(0.18127)$ & $(1.34515)$ & $(0.99932)$ & $(0.10634)$ & $(0.12007)$ & $(0.17175)$ \\
\hline & {$[-1.67494]$} & {$[-0.74271]$} & {$[-0.60175]$} & {$[0.39606]$} & {$[0.32016]$} & {$[-0.75819]$} \\
\hline \multirow[t]{3}{*}{ D(G20_IMPR(-1)) } & 0.358260 & -0.040383 & 0.094984 & -0.011233 & 0.043105 & 0.129273 \\
\hline & $(0.17759)$ & $(1.31784)$ & $(0.97903)$ & $(0.10418)$ & $(0.11764)$ & $(0.16826)$ \\
\hline & [2.01739] & {$[-0.03064]$} & {$[0.09702]$} & {$[-0.10782]$} & {$[0.36643]$} & {$[0.76828]$} \\
\hline \multirow[t]{3}{*}{ D(G20_EXPR $(-1))$} & -0.373140 & 0.137086 & -0.074054 & 0.011045 & -0.048770 & -0.112331 \\
\hline & $(0.22867)$ & $(1.69693)$ & $(1.26066)$ & $(0.13415)$ & $(0.15148)$ & $(0.21667)$ \\
\hline & {$[-1.63178]$} & {$[0.08078]$} & {$[-0.05874]$} & {$[0.08234]$} & {$[-0.32196]$} & {$[-0.51845]$} \\
\hline \multirow[t]{3}{*}{$\mathrm{D}\left(\mathrm{G} 20 \_\operatorname{UER}(-1)\right)$} & -1.920714 & 10.33801 & 6.677376 & -0.350338 & 0.032457 & -0.114525 \\
\hline & $(0.89130)$ & $(6.61419)$ & $(4.91373)$ & $(0.52288)$ & $(0.59041)$ & $(0.84451)$ \\
\hline & {$[-2.15496]$} & {$[1.56300]$} & {$[1.35892]$} & {$[-0.67001]$} & {$[0.05497]$} & {$[-0.13561]$} \\
\hline \multirow[t]{3}{*}{ D(G20_FDIR(-1)) } & -1.260999 & 3.300690 & 2.087392 & -0.589382 & 0.242055 & 0.106050 \\
\hline & $(0.66178)$ & $(4.91097)$ & $(3.64839)$ & $(0.38824)$ & $(0.43838)$ & $(0.62704)$ \\
\hline & {$[-1.90547]$} & {$[0.67211]$} & {$[0.57214]$} & {$[-1.51810]$} & {$[0.55216]$} & {$[0.16913]$} \\
\hline \multirow[t]{3}{*}{ D(G20_GSAVR(-1)) } & -1.400896 & -4.104616 & -3.095127 & 0.137341 & -0.388135 & -0.673223 \\
\hline & $(0.47170)$ & $(3.50040)$ & $(2.60047)$ & $(0.27672)$ & $(0.31246)$ & $(0.44694)$ \\
\hline & {$[-2.96991]$} & {$[-1.17261]$} & {$[-1.19022]$} & {$[0.49631]$} & {$[-1.24219]$} & {$[-1.50630]$} \\
\hline \multirow[t]{3}{*}{$\mathrm{C}$} & -0.627830 & 0.253668 & 0.007480 & -0.034127 & -0.024316 & 0.074658 \\
\hline & $(0.24931)$ & $(1.85006)$ & $(1.37442)$ & $(0.14626)$ & $(0.16514)$ & $(0.23622)$ \\
\hline & {$[-2.51832]$} & [0.13711] & {$[0.00544]$} & {$[-0.23334]$} & {$[-0.14724]$} & {$[0.31606]$} \\
\hline
\end{tabular}

The second section represents the short-term relationship of the variables. The first line shows us that the deviation of the previous periods from the long-term equilibrium is corrected in the current period as an adjustment speed of $41.3 \%$. The other rows in line with the variables imports, exports, unemployment, FDI and gross savings give percentage changes in inflation associated with either an increase (IMPR) or a decrease (EXPR, UER, FDIR, GSAVR) in the short-run average.

To detect the true relationship status of our variables in the short run, we perform the Wald test. We can see in Table 7 of the Wald Test result that the Chi-square probability is higher than the alpha (0.05). This means that we cannot reject the null hypothesis (there is no short-term causal relationship between the variables).

In Table 8 of the SSA case, we can see the long-run cointegration equation for the variables. The $\mathrm{ECT}_{\mathrm{t}-1}=1.000 \mathrm{ssa}-\mathrm{inflr}_{\mathrm{t}-1}+0.206 \mathrm{ssa}-\mathrm{impr}_{\mathrm{t}-1}-0.295 \mathrm{ssa}-$ expr $_{\mathrm{t}-1}+$ 2.004 ssa-uer ${ }_{t-1}+2.221$ ssa-fdir $r_{t-1}-0.238 s s a-$ gsavr $_{t-1}+13.093$.

The deviation of the previous periods from the long-term equilibrium is corrected in the current period as an adjustment speed of $117.1 \%$. The other rows are in line with the variables imports, exports, unemployment, FDI and gross 
Table 7. G20 Wald test.

\begin{tabular}{|c|c|c|c|}
\hline \multicolumn{3}{|c|}{ Equation: Untitled } & \multirow[b]{2}{*}{ Probability } \\
\hline Test Statistic & Value & $\mathrm{df}$ & \\
\hline F-statistic & 2.195080 & $(5,13)$ & 0.1177 \\
\hline Chi-square & 10.97540 & 5 & 0.0519 \\
\hline
\end{tabular}

Table 8. SSA VECM.

\begin{tabular}{|c|c|c|c|c|c|c|}
\hline Cointegrating Eq: & CointEq1 & & & & & \\
\hline SSA_INFLR(-1) & 1.000000 & & & & & \\
\hline \multirow[t]{3}{*}{ SSA_IMPR $(-1)$} & 0.206938 & & & & & \\
\hline & $(0.04944)$ & & & & & \\
\hline & [4.18524] & & & & & \\
\hline \multirow[t]{3}{*}{ SSA_EXPR $(-1)$} & -0.295493 & & & & & \\
\hline & $(0.06037)$ & & & & & \\
\hline & {$[-4.89468]$} & & & & & \\
\hline \multirow[t]{3}{*}{ SSA_UER(-1) } & 2.004070 & & & & & \\
\hline & $(0.33154)$ & & & & & \\
\hline & {$[6.04471]$} & & & & & \\
\hline \multirow[t]{3}{*}{ SSA_FDIR(-1) } & 2.221087 & & & & & \\
\hline & $(0.38885)$ & & & & & \\
\hline & [5.71197] & & & & & \\
\hline \multirow[t]{3}{*}{ SSA_GSAVR $(-1)$} & -0.238325 & & & & & \\
\hline & $(0.04728)$ & & & & & \\
\hline & {$[-5.04023]$} & & & & & \\
\hline $\mathrm{C}$ & -13.09300 & & & & & \\
\hline Error Correction: & D(SSA_INFLR) & D(SSA_IMPR) & D(SSA_EXPR) & D(SSA_UER) & D(SSA_FDIR) & D(SSA_GSAVR) \\
\hline \multirow[t]{3}{*}{ CointEq1 } & -1.171633 & -0.316814 & 1.251630 & -0.057184 & 0.097288 & 0.294082 \\
\hline & $(0.41035)$ & $(2.63640)$ & $(2.25892)$ & $(0.04915)$ & $(0.13543)$ & $(0.75210)$ \\
\hline & {$[-2.85519]$} & {$[-0.12017]$} & {$[0.55408]$} & {$[-1.16335]$} & {$[0.71835]$} & [0.39101] \\
\hline \multirow[t]{3}{*}{ D(SSA_INFLR(-1)) } & 0.065636 & -0.734235 & -2.489388 & 0.004867 & 0.062287 & -0.234725 \\
\hline & $(0.29192)$ & $(1.87552)$ & $(1.60698)$ & $(0.03497)$ & $(0.09635)$ & $(0.53504)$ \\
\hline & {$[0.22484]$} & {$[-0.39148]$} & {$[-1.54911]$} & [0.13919] & [0.64649] & {$[-0.43870]$} \\
\hline \multirow[t]{3}{*}{ D(SSA_IMPR(-1)) } & 0.114660 & -0.193555 & 0.142702 & -0.004352 & -0.018944 & -0.059142 \\
\hline & $(0.05076)$ & $(0.32611)$ & $(0.27942)$ & $(0.00608)$ & $(0.01675)$ & $(0.09303)$ \\
\hline & {$[2.25894]$} & {$[-0.59353]$} & {$[0.51072]$} & {$[-0.71585]$} & {$[-1.13083]$} & {$[-0.63573]$} \\
\hline \multirow[t]{3}{*}{ D(SSA_EXPR(-1)) } & -0.087840 & -0.342110 & -0.234982 & -0.007759 & 0.022502 & 0.003005 \\
\hline & $(0.06971)$ & $(0.44786)$ & $(0.38374)$ & $(0.00835)$ & $(0.02301)$ & $(0.12776)$ \\
\hline & {$[-1.26010]$} & {$[-0.76387]$} & {$[-0.61235]$} & {$[-0.92919]$} & {$[0.97804]$} & {$[0.02352]$} \\
\hline
\end{tabular}




\begin{tabular}{ccccccc} 
Continued & \multicolumn{7}{c}{} \\
\hline D(SSA_UER(-1)) & $-\mathbf{2 . 0 5 3 0 3 8}$ & 14.97393 & 6.441622 & 0.456118 & 0.453870 & 3.209314 \\
& $(2.13143)$ & $(13.6939)$ & $(11.7332)$ & $(0.25532)$ & $(0.70346)$ & $(3.90652)$ \\
& {$[-0.96322]$} & {$[1.09348]$} & {$[0.54901]$} & {$[1.78647]$} & {$[0.64520]$} & {$[0.82153]$} \\
D(SSA_FDIR(-1)) & 2.409965 & -1.299290 & -0.590901 & -0.134075 & -0.043534 & -0.394851 \\
& $(1.17431)$ & $(7.54461)$ & $(6.46437)$ & $(0.14067)$ & $(0.38757)$ & $(2.15229)$ \\
& {$[2.05225]$} & {$[-0.17221]$} & {$[-0.09141]$} & {$[-0.95314]$} & {$[-0.11233]$} & {$[-0.18346]$} \\
D(SSA_GSAVR(-1)) & -0.643102 & 2.170130 & -1.064514 & -0.017856 & -0.104613 & -0.247770 \\
& $(0.25895)$ & $(1.66370)$ & $(1.42549)$ & $(0.03102)$ & $(0.08547)$ & $0.47461)$ \\
& {$[-2.48348]$} & {$[1.30440]$} & {$[-0.74677]$} & {$[-0.57565]$} & {$[-1.22404]$} & {$[-0.52205]$} \\
& -0.108577 & 0.136385 & -1.116133 & 0.005201 & -0.053821 & -0.198124 \\
& $(0.34129)$ & $(2.19271)$ & $(1.87876)$ & $(0.04088)$ & $(0.11264)$ & $(0.62553)$ \\
& {$[-0.31814]$} & {$[0.06220]$} & {$[-0.59408]$} & {$[0.12721]$} & {$[-0.47781]$} & {$[-0.31673]$} \\
\hline
\end{tabular}

Table 9. SSA Wald test.

\begin{tabular}{|c|c|c|c|}
\hline \multicolumn{3}{|c|}{ Equation: Untitled } & \multirow[b]{2}{*}{ Probability } \\
\hline Test Statistic & Value & $\mathrm{df}$ & \\
\hline F-statistic & 1.819150 & $(5,13)$ & 0.1782 \\
\hline Chi-square & 9.095752 & 5 & 0.1053 \\
\hline
\end{tabular}

savings give percentage changes in inflation associated with either an increase (IMPR, FDIR) or a decrease (EXPR, UER, GSAVR) in the short-run average.

In Table 9, the Wald Test has a Chi-square probability that is higher than the alpha (0.05). This means that we cannot reject the null hypothesis (there is no short-term causal relationship between the variables).

\subsection{Breusch-Godfrey Serial Correlation LM Test and CUSUM Test}

The correlation test allows us to know if our series are correlated or not. And the CUSUM test allows us to analyse the stability of our series.

Table 10 shows that the Chi-Square probability is greater than the alpha, which means that there is no correlation between our series.

The output of the CUSUM test in Figure 5 shows that our residuals are stable. The CUSUM line remains in the middle of the significance line.

Table 11 of SSA case shows that the Chi-Square probability is also greater than the alpha, which means that there is no correlation between our series.

Table 10. G20 LM test.

\begin{tabular}{|c|c|c|c|}
\hline \multicolumn{4}{|c|}{ Breusch-Godfrey Serial Correlation LM Test: } \\
\hline \multicolumn{4}{|c|}{ Null hypothesis: No serial correlation at up to 1 lag } \\
\hline F-statistic & 0.000248 & Prob. $F(1,12)$ & 0.9877 \\
\hline $\mathrm{Obs}^{\star} \mathrm{R}$-squared & 0.000434 & Prob. Chi-Square(1) & 0.9834 \\
\hline
\end{tabular}


Table 11. SSA LM test.

Breusch-Godfrey Serial Correlation LM Test:

Null hypothesis: No serial correlation at up to 1 lag

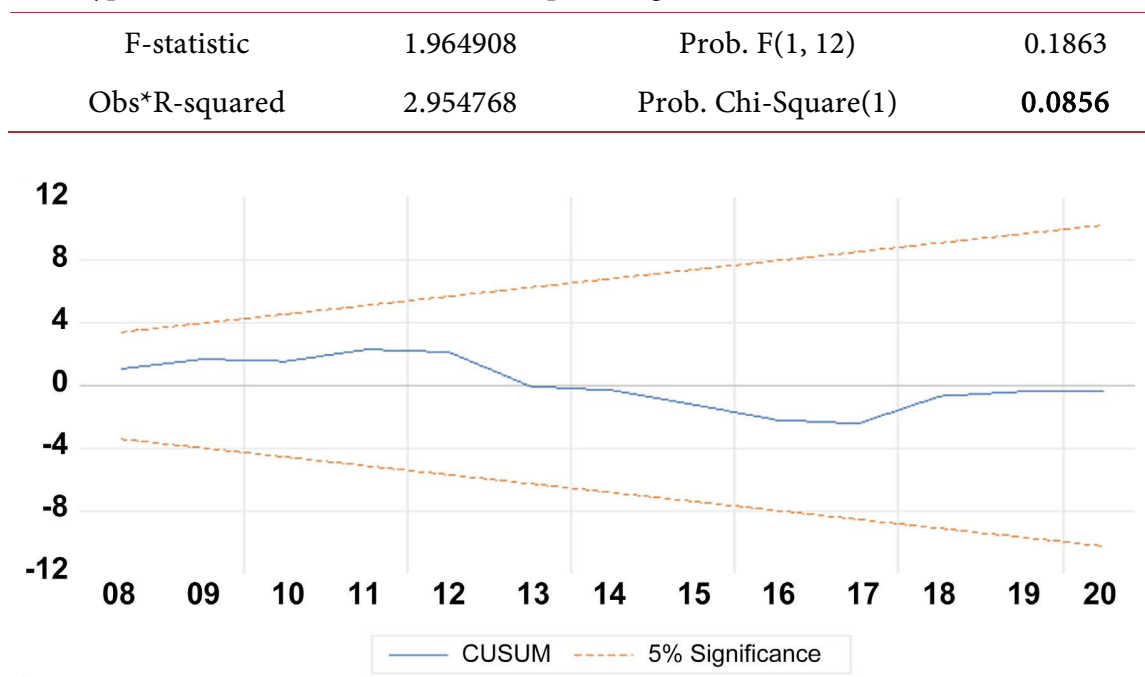

Figure 5. G20 CUSUM test.

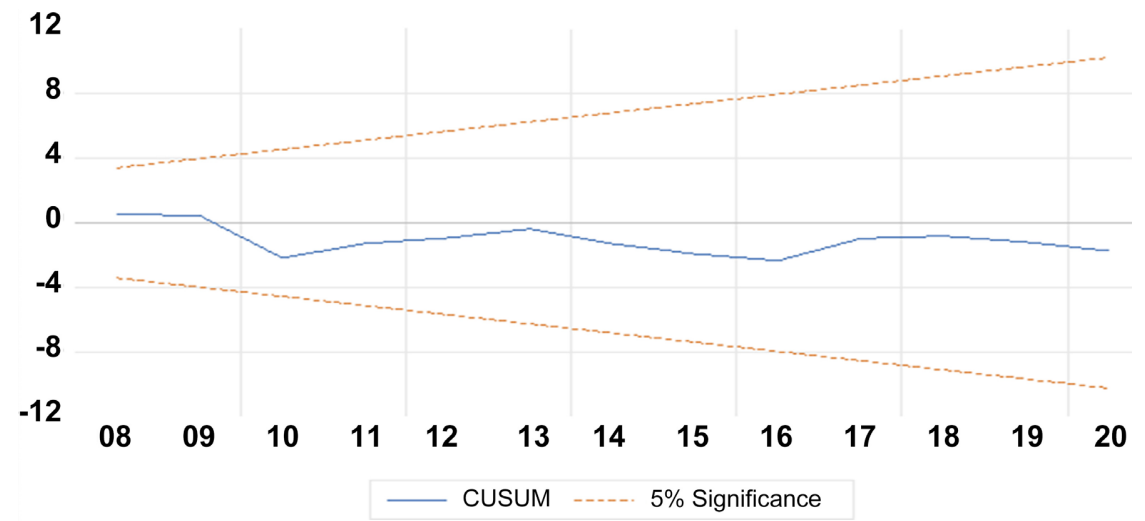

Figure 6. SSA CUSUM test.

The output of the SSA CUSUM test in Figure 6 also shows that our residuals are stable.

\section{Summary and Conclusion}

The question of the relationship between inflation and other economic indicators remains controversial. The results of studies in this area vary according to the dependent and independent variables, their interrelationships and the macroeconomic criteria and elements considered. Indeed, inflation emerges from macroeconomic uncertainties, and many empirical studies have been conducted in this area, but no emphasis has been placed on the disparity in results between developed and transition economies. This paper has examined the equivocation attached to this issue by opening up a new direction to all the work previously done. The results can be summarized in three approaches. 
The first is an overview of inflation and its environment in the different regions considered in the study. The particular point to note is that the characteristics of an increase in inflation are often related to changes in supply and demand, price movements, income and investment, which constitute both the drivers and the costs of inflation. In economic terms, when inflation occurs, firms typically adjust their prices in line with cost changes in order to stabilize their profits. And this change leads in the long run to an increase in wages and a decrease in consumer purchasing power, which will be accompanied by a decrease in the money supply, as consumers will be more interested in saving than spending. According to Pettinger (2017), from a financial perspective, the presence of inflation leads to a decrease in investment due to market uncertainty and reduced returns on assets. Similarly, there is a reduction in debt and an increase in the cost of debt. As Zeder (2020) points out, when inflation is high, it reduces the value of debt and makes it easier to repay. However, this represents a cost for creditors who see the value of their claims decrease. On the other hand, as Beggs (2019) points out, in trade terms, the impact of inflation is felt directly on the balance of trade, which harms a country's international competitiveness. Indeed, its exports will decrease and its imports will become more expensive.

According to the June 2019 IMF (International Monetary Fund, 2019), considering some of the economic realities of the G20, such as in 2019, where monetary policies have been eased a lot. Indeed, the easing advocated for the first time in 2018 was aimed at increasing growth and banishing the risks of low inflation. Of course, due to the economic recession experienced by some of these member states, the G20 had to do something about it. The result was a situation of lower growth and therefore no inflation. While in SSA, in 2016, there was an increase in oil prices, a situation that was repeated in 2018 with an increase in public debts, weakening aggregate demand, low growth and an increase in interest rates. Indeed, it would appear that there remains negative linearity between growth and interest rates as the two move in opposite directions.

The second approach concerns the relationship between the level of development of a country and its inflation rate. The econometric model applied suggests that the inflation rate varies with the level of development of a country in the long run. Indeed, with a high level of development, monetary policy for a country becomes a strategy guided by the economic situation of the moment and the consideration of all macroeconomic criteria. In this case, inflation appears to be a strategic tool. In developing countries, however, this remains a challenge, as many of them are still on the bangs of the right macroeconomic criteria. However, in the context of developing countries, inflation appears more like a picture of growth, even if the passivity of monetary policies in these countries stagnate inflation and turns it into economic weakness.

Finally, the last approach refers to the analysis of the short-term relationship of our variables, which according to the results is non-existent. This leads us to consider the long-run relationship as ambiguous. Indeed, there is always a subtle 
uncertainty around inflation, even the economic signals and indicators often inform at this level. Inflation is and remains controversial because considering the equivocal, multi-voiced and polemical results that remain around its stimuli, it still requires deep analysis. However, let's remember that one of the reasons that sometimes blur the results of these analyses is that some of its stimulants play both a triggering and a restorative role. This is the case, for example of the growth rate, the interest rate, and so on.

Finally, we note that our results are attributed to the overall macroeconomic characteristics and realities of the two regions (G20, SSA). Thus, further work will be needed to more specifically address and deepen this issue by examining macroeconomic policies between two countries for more relevance.

\section{Conflicts of Interest}

The author declares no conflicts of interest regarding the publication of this paper.

\section{References}

Abdul, J., Rabbia, T., \& Nazia, B. (2014). Fiscal Deficit and Inflation: New Evidences from Pakistan Using a Bounds Testing Approach. Economic Modelling, 37, 120-126. https://doi.org/10.1016/j.econmod.2013.10.029

Barnichon, R., \& Peiris, S. J. (2008). Sources of Inflation in Sub-Saharan Africa. Journal of African Economies, 17, 729-746. https://doi.org/10.1093/jae/ejn002

Beggs, J. (2019). The Costs of Inflation. Thought Co., March 2019.

Bick, A., Kremer, S., \& Nautz, D. (2009). Inflation and Growth: New Evidence from a Dynamic Panel Threshold Analysis. SFB Discussion Paper 036.

Bruno, M., \& Easterly, W. (1998). Inflation Crisis and Long-Run Growth. Journal of Monetary Economics, 41, 19-21. https://doi.org/10.1016/S0304-3932(97)00063-9

Camara, Y. (2014). Exchange Rate Regimes and Economic Performance in Sub-Saharan Africa (pp. 194-196). HAL Archives ouverts.com, December 2014.

Cheikh, T., \& Mamadou, K. (2017). The Role of Inflation Uncertainty on Economic Growth: The Case of the WAEMU(p. 2).

Daal, E., Naka, A., \& Sanchez, B. (2005). Re-Examining Inflation and Inflation Uncertainty in Developed and Emerging Countries. Economics Letters, 89, 180-186. https://doi.org/10.1016/j.econlet.2005.05.024

Diez, S., \& O’Donnell, D. (2017). G20 in Figures: Summit of the G20 States in Hamburg 2017 (p. 17). Federal Statistical Office, June 2017.

Dotsey, M., \& Sarte, P. D. (2000). Inflation Uncertainty and Growth in a Cash-Advance Economy. Journal of Monetary Economics, 45, 631-655. https://doi.org/10.1016/S0304-3932(00)00005-2

Evans, M. (1991). Discovering the Link between Inflation Rates and Inflation Uncertainty. Journal of Money, Credit and Banking, 23, 169-184.

https://doi.org/10.2307/1992775

Fisher, S. (1993). The Role of Macroeconomic Factors in Growth. Journal of Monetary Economics, 32, 485-512. https://doi.org/10.1016/0304-3932(93)90027-D

Fountas, S., Karanasos, M., \& Kim, J. (2007). Inflation Uncertainty, Output Growth Un- 
certainty and Macroeconomic Performance. Oxford Bulletin of Economics and Statistics, 68, 319-343. https://doi.org/10.1111/j.1468-0084.2006.00164.x

Gali, J., \& Monacelli, T. (2008). Optimal Monetary and Fiscal Policy in a Currency Union. Journal of International Economics, 76, 116-132. https://doi.org/10.1016/j.jinteco.2008.02.007

Ghosh, A., \& Phillips, S. (1998). Warning: Inflation May Be Harmful to Your Growth. IMF Staff, 45, 672-710. https://doi.org/10.2307/3867589

Gillman, M., \& Kejak, M. (2005). Inflation and Balanced-Path Growth with Alternative Payment Mechanisms. Economic Journal, 115, 247-270. https://doi.org/10.1111/j.1468-0297.2004.00968.x

Global Economic Prospects (2015). Sub-Saharan Africa. https://www.worldbank.org/content/dam/Worldbank/GEP/GEP2015b/Global-Econom ic-Prospects-June-2015-Sub-Saharan-Africa-analysis.pdf

Grier, K. B., \& Perry, M. J. (1998). On Inflation and Inflation Uncertainty in the G7 Countries. Journal of International Money and Finance, 17, 671-689. https://doi.org/10.1016/S0261-5606(98)00023-0

Holland, A. S. (1995). Inflation and Uncertainty: Tests for Temporal Ordering. Journal of Money, Credit and Banking, 27, 827-837. https://doi.org/10.2307/2077753

Igor, P. (2006). Money Demand and Inflation in Belarus: Evidence from Cointegrated VAR. Research in International Business and Finance, 20, 200-214. https://doi.org/10.1016/j.ribaf.2005.09.002

IMF (2015, February). G-20 Finance Ministers and Central Bank Governors Meeting, Global Prospects and Policy Challenges (pp. 1 and 2S).

International Monetary Fund (2019, June). G-20 Surveillance Note. G-20 Finance Ministers and Central Bank Governors' Meetings June 8-9, 2019 Fukuoka, Japan. https://www.imf.org/external/np/g20/pdf/2019/060519.pdf

Khan, M., \& Senhadji, A. (2001). Threshold Effects in the Relationship between Inflation and Growth. IMF Staff Paper, 48, 1-21.

Levy-Yeyati, E., \& Sturzenegger, F. (2007). Fear of Floating in Reverse: Exchange Rate Policy in the 2000s. World Bank.

Loungani, P., \& Swagel, P. (2001). Sources of Inflation in Developing Countries (p. 10). IMF Working Paper 01/198: 29.

Luis, A., \& Marco, E. (2005). Fiscal Deficits and Inflation. Journal of Monetary Economics, 52, 529-554. https://doi.org/10.1016/j.jmoneco.2004.06.003

Masson, P. (2000). Exchange Rate Regime Transition. IMF Working Paper (134). https://doi.org/10.5089/9781451855593.001

Michael, B., \& William, E. (1998). Inflation Crises and Long-Run Growth. Journal of Monetary Economics, 41, 3-26. https://doi.org/10.1016/S0304-3932(97)00063-9

Newiak, M. (2016, October). Sub-Saharan Africa: Policy Adjustment Way Out of Growth Slump. International Monetary Fund Africa Department.

Nezir, K., Furkan, E., \& Sezgin, A. (2012). The Interest Rate-Inflation Relationship under an Inflation Targeting Regime: The Case of Turkey. Journal of Asian Economics, 23, 476-485. https://doi.org/10.1016/j.asieco.2012.03.001

Peter, R., \& Hakan, Y. (2009). Inflation, Financial Development, and Growth: A Trilateral Analysis. Economic Systems, 33, 310-324. https://doi.org/10.1016/j.ecosys.2009.06.002

Pettinger, T. (2017). Is Inflation Harmful? Economics. Help, November 2017. https://www.economicshelp.org/macroeconomics/inflation/inflation-essay-harmful/ 
Rudra, P., Mak, B., \& Sahar, B. (2015). Causal Nexus between Economic Growth, Inflation, and Stock Market Development: The Case of OECD Countries. Global Finance Journal, 27, 98-111. https://doi.org/10.1016/j.gfj.2015.04.006

Sarel, M. (1996). Nonlinear Effects of Inflation on Economic Growth. IMF Staff Papers, 43, 199-215. https://doi.org/10.2307/3867357

Sargent, T., \& Wallace, N. (1981). Some Unpleasant Monetarist Arithmetic. Federal Reserve Bank of Minneapolis Quarterly Review, 5, 1-17. https://doi.org/10.21034/qr.531

Siok, K., Xue, Q., \& Yen, N. (2015). A Comparative Study on the Effects of Oil Price Changes on Inflation. Procedia Economics and Finance, 26, 630-636. https://doi.org/10.1016/S2212-5671(15)00800-X

Taylor, J. B. (1993). Macroeconomic Policy in a World Economy: From Econometric Design to Practical Operation. W.W. Norton \& Company, Inc.

The World Bank (n.d.). Inflation, Consumer Prices (Annual \%)—Sub-Saharan Africa, Middle East \& North Africa.

https://data.worldbank.org/indicator/FP.CPI.TOTL.ZG?locations=ZG-ZQ

World Bank (n.d.). Sub-Saharan Africa Foreign Direct Investment 1970-2021.

https://www.macrotrends.net/countries/SSF/sub-saharan-africa-/foreign-direct-invest ment

Zeder, R. (2020). The Costs of Inflation. Quickonomics, March 2020.

https://quickonomics.com/the-costs-of-inflation/ 